\title{
The Effect of Mexidel on Brain Natriuretic Peptide of Cardiomyocytes in a Post-Reperfusion Period in Experinent
}

D01. 10. $17691 / \mathrm{stm} 2015.7 .3 .05$

Received February 5, 2015

M.L. Bugrova, PhD, Associate Professor, Head of Electron Microscopy Unit, Central Scientific Research Laboratory;

D.A. Abrosimov, PhD Student, Department of Histology with Cytology and Embryology;

E.I. Yakovleva, PhD, Senior Researcher, Electron Microscopy Unit, Central Scientific Research Laboratory

Nizhny Novgorod State Medical Academy, 10/1 Minin and Pozharsky Square, Nizhny Novgorod, 603005, Russian Federation

Brain natriuretic peptide (BNP) participates in electrolyte balance maintenance in the body playing a critical part in the pathogenesis of cardiovascular diseases, and has the prognostic value in clinical presentation. It is of interest to analyze the peculiarities of BNP interaction with medicinal drugs, e.g. Mexidol, an antihypoxic agent of metabolic type that has a cardioprotective effect and is widely used in cardiology. The effect of Mexidol on BNP in a post-reperfusion period was studied for the first time.

The aim of the investigation was to estimate the effect of Mexidol on BNP accumulation and release intensity in cardiomyocyte granules in rats in a post-reperfusion period.

Materials and Methods. The experiments were carried out on 25 outbred male rats weighing $220-250 \mathrm{~g}$. Total ischemia (10 min) was modeled by cardiovascular bundle compression according to Korpachev. Mexidol was administered intermittently, it being injected intraperitoneally after resuscitation, every 20 min within the first hour. BNP accumulation and release intensity was assessed by a quantitative analysis of immunolabeled granules of atrial myocytes under a transmission electron microscope.

Results. Mexidol administered at a dose of $25 \mathrm{mg} / \mathrm{kg}$ body mass within the first hour reperfusion after 10 min of total ischemia has a positive prolonged effect on BNP: after 60 days of a postperfusion period the processes of peptide accumulation and release in atrial myocytes of rats enhance resulting in an additional cardioprotective effect. The increase of BNP release against high synthetic and proliferative activity of fibroblasts contributes to the reduction of cardiosclerosis development in a long-term post-reperfusion period.

The study of immunolabeled granules of BNP myocytes in rat right atrium enabled to discover a new mechanism of a cardioprotective effect of Mexidol in a long-term post-reperfusion period.

Conclusion. Mexidol has a prolonged effect on brain natriuretic peptide and significantly enhances its accumulation and release in atrial cardiomyocytes of rats in a long-term post-reperfusion period having an additional cardioprotective effect and reducing cardiosclerosis development.

Key words: brain natriuretic peptide; BNP; post-reperfusion period; Mexidol.

Brain natriuretic peptide (BNP) discovered in 1988 belongs to natriuretic peptides able to reduce arterial pressure and maintain electrolyte balance by stimulating diuresis and natriuresis [1]. BNP is an antagonist of reninangiotensin-aldosteron system [1, 2]. The heart used to be considered as the main source of BNP: at first the peptide was revealed in ventricles, later - in secretory atrial granules. According to the present knowledge, BNP has been detected in fibroblasts and endotheliocytes of coronary arterial network [3, 4].

Currently, BNP is being actively studied due to its prognostic value in clinical practice as an effective marker of such diseases as myocardial infarction, ischemia, arrhythmia, acute decompensated heart failure, atherosclerosis [5-8]. The capabilities of its therapeutic application are being under study as well [914]. It has given rise to the investigation of BNP synthesis and release under the conditions of cardiovascular pathology.

In the therapy of postresuscitation complications, the so called antihypoxic agents of metabolic type are used as they aim at the correction of intracellular

For contacts: Bugrova Marina Leonidovna, e-mail: marysmir@mail.ru 
damage under hypoxia. Among such pharmaceuticals, Mexidol - a domestic medicinal agent (succinatecontaining 3-hydroxy pyridine derivative) has obtained a widespread use [15, 16]. Neuro- and cardioprotective effect of Mexidol in a post-reperfusion period (PRP) has been shown in clinical practice and experiments [1517]. Earlier, we studied the effect of Mexidol on atrial natriuretic peptide (ANP) in an isolated perfused heart in a whole body an hour after PRP. We revealed a marked positive effect on the peptide formation and release $[18,19]$. BNP and ANP are considered to have much in common: they activate similar receptors of target organs, which realize their physiological effects through a cascade of cGMP-dependent cellular reactions. Actually, the same factors influence the synthesis of both peptides: arterial pressure elevation, hypoxia, activation of renin-angiotensin-aldosteron system, etc. [1].

The difference between ANP and BNP consists in the following: ANP starts releasing in blood in response to short-term arterial pressure elevation and is quickly inactivated by endopeptidase. BNP requires longer influence, and its circulation time in blood is longer; as a result, the peptide came into use in clinical practice as a prognostic agent [20].

All the above mentioned made us study the effect of Mexidol on BNP synthesis and release.

The aim of the investigation was to estimate the effect of Mexidol on brain natriuretic peptide accumulation and release in cardiomyocyte granules in rats in a postreperfusion period.

Materials and Methods. The experiments were carried out on 25 outbred male rats weighing 220$250 \mathrm{~g}$ in accordance with the European Convention for Protection of Vertebrate Animals used with Experimental and other Scientific Purposes (the Convention took place in Strasbourg on March, 18, 1986 and was confirmed in Strasbourg on June, 15, 2006). Total ischemia according to Korpachev was modeled by 10-minute occlusion of the cardiovascular bundle [21]. The animals were divided into 5 groups: group 1 $(n=5)$ - intact animals; group 2 $(n=5)$ - control, 60 min of PRP; group $3(n=5)-60$ min of PRP + Mexidol; group $4(n=5)$ - control, 60 days of PRP; group $5(n=5)-$ 60 days of PRP + Mexidol.

Group 3 and 5 animals were administered Mexidol intermittently and injected intraperitoneally within the first hour after resuscitation, at the dose of $25 \mathrm{mg} / \mathrm{kg}$ body mass, every $20 \mathrm{~min}$. The therapeutic effect of Mexidol is known to manifest experimental animals in the dose range from 10 to $300 \mathrm{mg} / \mathrm{kg}$ : Mexidol at the dose of $25 \mathrm{mg} / \mathrm{kg}$ has a marked vasoprotective and cardioprotective effect [16].

We carried out the electron microscopic analysis of the right atrial tissue samples according to a standard technique [22]. Immunocytochemical reactions to reveal BNP localization were carried out on ultrathin sections using polyclonal antibodies Rabbit anti-Brain Natriuretic Peptide-32 (Rat) Serum (Peninsula Laboratories Inc., USA) and antibodies Protein-A/Gold (15 nm) (EM Grade, Electron Microscopy Sciences, USA). The sections were counterstained by uranyl acetate, lead citrate, and studied under an electron microscope Morgagni 268D (FEl, USA). In accordance with the classification of secretory cardiomyocyte granules, two types of granules were distinguished: A-type - mature, storing, and B-type - dissolving [23]. The granules were counted per field of vision $\left(38 \times 38 \mu \mathrm{m}^{2}\right)$. The data were statistically processed by Statistica 10.0 program using MannWhitney test $(p<0.05)$.

\section{Results}

60 min after PRP the quantitative analysis of the right atrial secretory myocyte granules of group 3 animals (60 min of PRP + Mexidol) containing BNP-immunoreactive material revealed the significant increase (by $93 \%$ ) of A-type granules, B-type - by $147 \%$ compared to the intact animals (Figure 1). Group 2 (60 min of PRP) showed no significant changes.

During this period, in group 3 the change of secretory myocyte ultrastructure was evident as slight clarification of mitochondrial matrix and dilated cisterns of sarcoplasmic reticulum. Nuclei had euchromatin, in sarcoplasm there was a considerable amount of cytoplasmic granules (Figure 2). In group 2, swollen mitochondria prevailed, the number of cytoplasmic granules visually being less

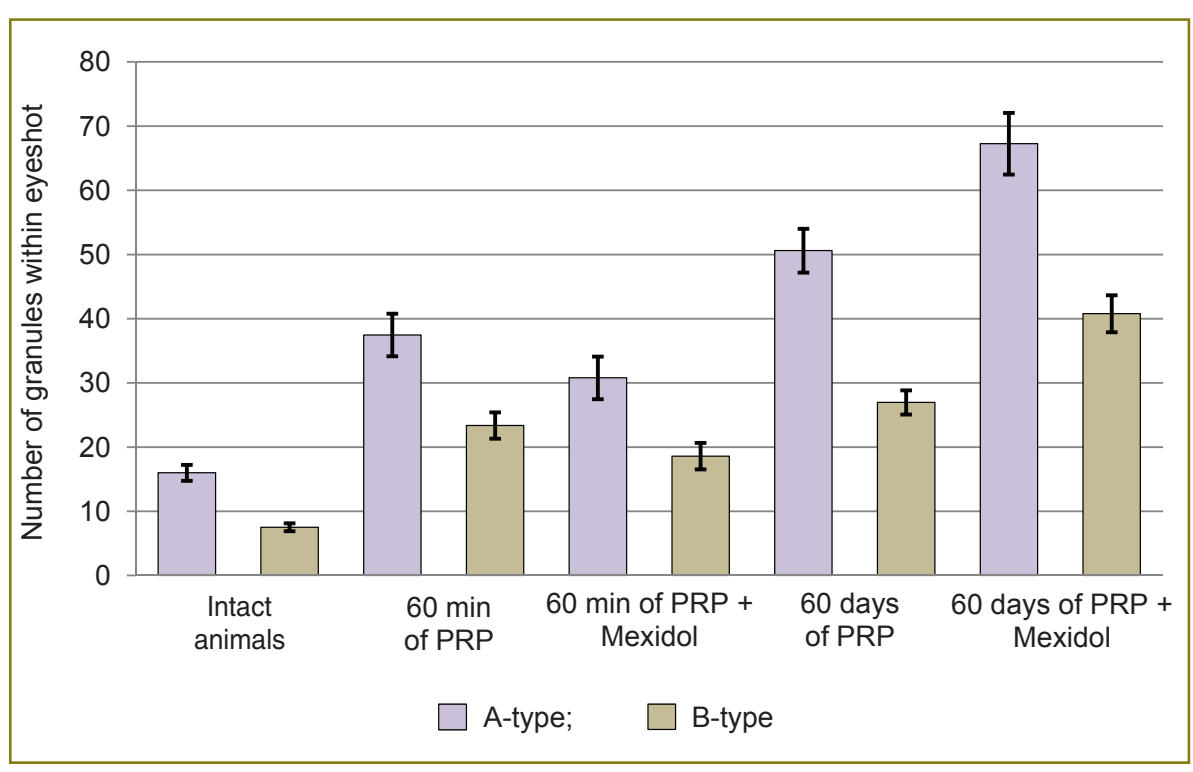

Figure 1. Quantitative distribution of granules with brain natriuretic peptide in intact and 
than that in group 3, and sarcoplasmic reticulum was dilated to a greater degree (Figure 3 ).

60 days after PRP the quantitative analysis of cardiomyocyte granules in group 5 ( 60 days of PRP + Mexidol) showed the growth of all type granules containing BNP compared to the indices in other groups. The number of A-type granules increased compared to the intact animals more than threefold, B-type - almost 4.5 time as much (See Figure 1). In group 4 (60 days of PRP) the content of secretory granules increased: A-type granules - by $33 \%$, and B-type granules - by $51 \%$.

Compared to the findings in group 3 ( 60 min of PRP + Mexidol) the number of granules in group 5 grew more than twofold: the number of A-type granules - by $118 \%$, B-granules - by $119 \%$. It is interesting to note that in group 4 the number of A-granules with BNP also

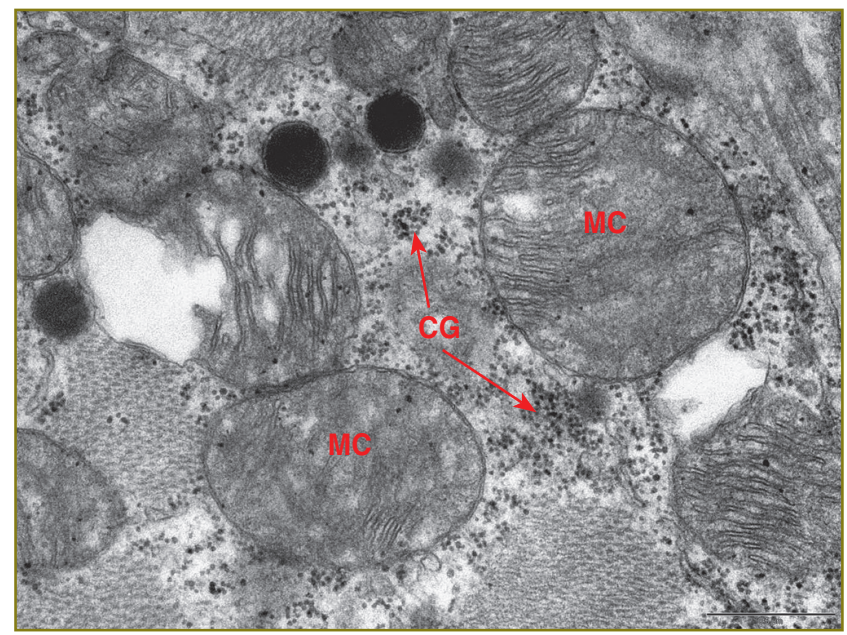

Figure 2. The right atrial cardiomyocyte ultrastructure $60 \mathrm{~min}$ after a post-reperfusion period using Mexidol. MC: mitochondria; CG: cytoplasmic granules; $\times 28,000$

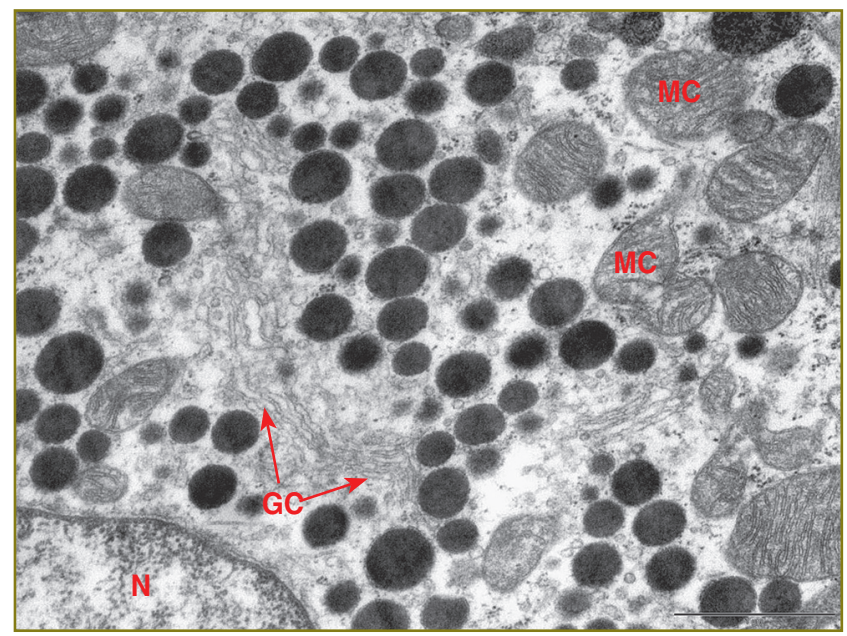

Figure 4. The right atrial cardiomyocyte ultrastructure 60 days after a post-reperfusion period using Mexidol. MC: mitochondria; GC: Golgi complex; N: nucleus; $\times 18,000$ increased (group 2) by $35 \%$ relating to an early PRP, the number of B-granules did not undergo significant changes.

During this period the right atrial myocardium of group 5 animals were found to have a marked synthetic activity of secretory cardiomyocytes: a great number of granules with the peptide, Golgi complex hypertrophy (Figure 4). Nuclei of most cells had euchromatin and nucleoli; visually, there were less cytoplasmic granules than in group 3 animals ( 60 min of PRP + Mexidol). The intercellular space was found to have the insignificant amount of collagen fibers.

Among cardiomyocytes in the myocardium of group 4 animals there were both necrotic and apoptotic cells. Some cardiomyocytes were revealed to have divergence of intercalated disks, there were swollen mitochondria,

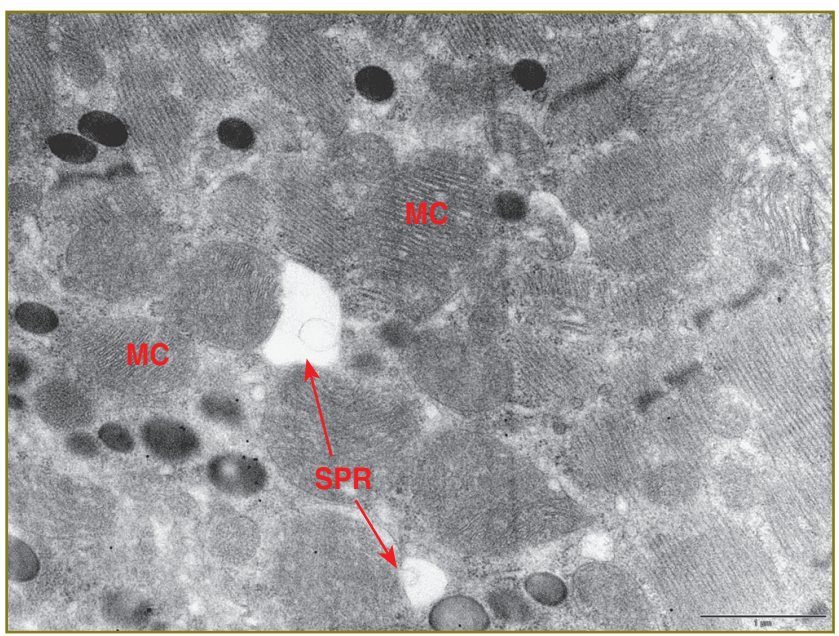

Figure 3. The right atrial cardiomyocyte ultrastructure $60 \mathrm{~min}$ after a post-reperfusion period. MC: mitochondria; SPR: sarcoplasmic reticulum; $\times 14,000$

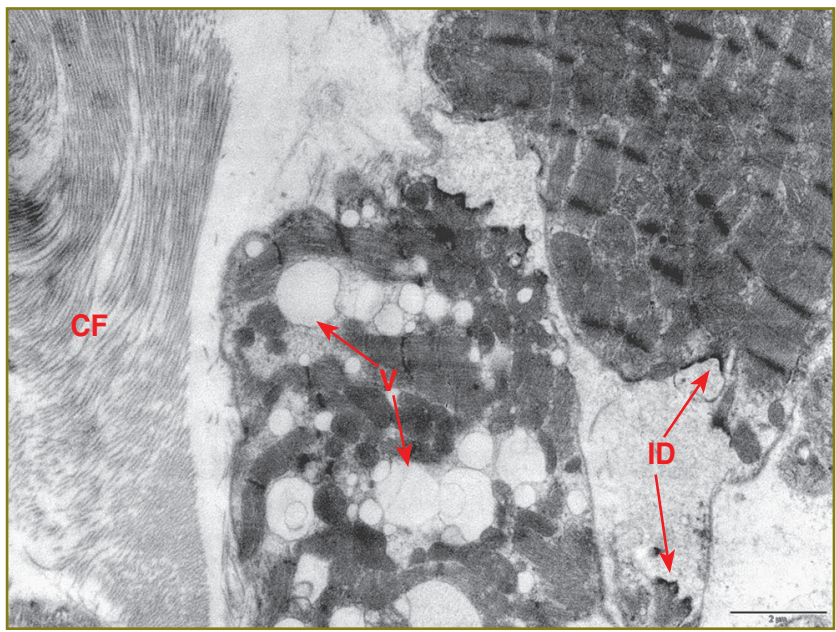

Figure 5. The right atrial cardiomyocyte ultrastructure 60 days after a post-reperfusion period. V: vacuoles; ID: intercalated disc; CF: collagen fibers; $\times 5,600$ 
vacuole formation, and the number of cytoplasmic granules was less than in group 5 animals (Figure 5). The intercellular space had significant increase of connective tissue components.

Discussion. In group 3, 60 min after PRP, after Mexidol administration, the increase of mature and dissolving granules with BNP indicated active BNP accumulation and release. On the other hand, the coincidence of quantitative indices with a control series without Mexidol administration indicated no effect of Mexidol on BNP synthesis and release during this period. Ischemic and reperfusion factors appeared to influence BNP through HIF (hypoxia inducible factors) activation in an early PRP and were principal ones both in the control and experimental groups. HIF- $1 \alpha$ has been found to trigger promotor in the sequence, which encodes BNP and stimulates transcription of its mRNA [24-26]. Ogawa and de Bold [1] have established BNP response to various pathological factors and the change of its plasma concentration to have much in common with ANP response. In the previous studies [19] we established a marked effect of Mexidol on ANP synthesis and release 60 min after circulation management under similar conditions. On the one hand, it can indicate significant differences in triggering mechanisms of formation and release of both peptides. On the other hand, it agrees the data of the authors [1] demonstrating the slower BNP response to different factors and the necessity for their longer influence. The morphological picture represented vasoprotective and cytoprotective effect of Mexidol on myocardium that was consistent with the findings of other researchers [17]. No red blood cell aggregation, maintenance of cardiomyocyte ultrastructure (slight dilation of sarcoplasmic reticulum cisterns, energized state of mitochondria, a great number of cytoplasmic granules) were due to antioxidant activity of 3-hydroxy pyridine and antihypoxic property of succinic acid. Succinate entering the intracellular space was oxidized by a respiratory chain under hypoxia; 3-hydroxy pyridine derivatives reduced microviscosity of membranes stabilizing a lipid component, inhibited lipid peroxidation processes, and had an impact on the activity of membrane-bound enzymes [16]. It is interesting to note that we observed the similar morphological picture when we studying cardiomyocytes of the rat Langendorf isolated heart, Mexidol being administered at the same dose $25 \mathrm{mg} / \mathrm{kg}$ [18]. In our experiment on rats we proved the heart to function on intracardiac level in an early PRP [27]. Mexidol in a whole body in this period was likely to have its effect just at intraorganic and intracellular levels [18].

60 days after the experiment, a great number of granules of both types in the right atrium of group 5 animals (Mexidol administration) and significant difference of all the indices compared to the animals of other groups indicated a marked stimulating effect of Mexidol on BNP accumulation and release in a long-term PRP. It can be assumed that Mexidol administered after resuscitation has an effect on BNP in two ways. On the one hand,
Mexidol has a direct prolonged effect on cardiac synthetic apparatus as evidenced by Golgi complex hypertrophy and a great number of granules. On the other hand, the low content of collagen fibers in intercellular space compared to a control series and the lack of necrotic cardiomyocytes indicate a marked cardioprotective effect of Mexidol on myocardium that can promote the enhancement of BNP synthesis and secretion. In our previous studies on ANP [28] we revealed a significant increase of all type granules with the peptide in rat myocardium in a long-term PRP. The increase of ANP accumulation and release proceeded against high synthetic and proliferative activity of fibroblasts; we considered a cardioprotective effect of the peptide as that contributing to the decrease of cardiosclerosis development. The control animals (with no Mexidol administered) were found to have a lot of granules with BNP that suggests the similarity of ANP and BNP effect under these conditions. According to other authors [29] BNP plays the main role in myocardial remodeling processes in patients with cardiovascular conditions. It has been shown by experiments [30] that BNP inhibits collagen synthesis, enhances the action of metalloproteases, and suppresses the proliferation of cardiac fibroblasts. The reduced amount of connective tissue component in myocardium of group 5 animals with previously administered Mexidol against an increased content of granules with BNP evidences the major role of the peptide as an anti-fibrosis factor in myocardium remodeling.

Thus, an experimental study of BNP in an early and long-term PRP in a whole body using a quantitative assay of immunolabeled granules of atrial myocytes enabled to reveal a prolonged positive effect of Mexidol at the dose of $25 \mathrm{mg} / \mathrm{kg}$ body mass on BNP synthesis and release, and confirm cardioprotective properties of Mexidol. The obtained results contribute to the study of BNP interaction with medicinal agents under cardiovascular pathology that is of scientific value and practical relevance.

Conclusion. Mexidol has a prolonged effect on brain natriuretic peptide and significantly enhances its accumulation and release in atrial cardiomyocytes of rats in a long-term post-reperfusion period having an additional cardioprotective effect and reducing cardiosclerosis development.

Study Funding. The study was performed within the frame of departmental research work "Systemic and molecular regulation mechanisms of physiological functions in health and disease" (2015-2017).

Conflicts of Interest. The authors have no conflict of interests to disclose.

\section{References}

1. Ogawa T., de Bold A.J. The heart as an endocrine organ. Endocr Connect 2014; 3(2): R31-R44, http://dx.doi.org/10.1530/ ec-14-0012. 
2. Sun Y., Deng T., Lu N., Yan M., Zheng X. B-type natriuretic peptide protects cardiomyocytes at reperfusion via mitochondrial calcium uniporter. Biomed Pharmacother 2010; 64(3): 170-176, http://dx.doi.org/10.1016/j.biopha.2009.09.024.

3. Jarai R., Kaun C., Weiss T.W., Speidl W.S., Rychli K., Maurer G., Huber K., Wojta J. Human cardiac fibroblasts express B-type natriuretic peptide: fluvastatin ameliorates its up-regulation by interleukin- $1 \alpha$, tumour necrosis factor- $\alpha$ and transforming growth factor- $\beta$. J Cell Mol Med 2009; 13(11-12): 4415-4421, http://dx.doi.org/10.1111/j.1582-4934.2009.00704.x.

4. de Bold A.J. Thirty years of research on atrial natriuretic factor: historical background and emerging concepts. Can J Physiol Pharmacol 2011; 89(8): 527-531, http://dx.doi. org/10.1139/y11-019.

5. Voulteenaho O., Ala-Kopsala M., Ruskoaho H. BNP as a biomarker in heart disease. Adv Clin Chem 2005; 40: 1-36, http://dx.doi.org/10.1016/s0065-2423(05)40001-3.

6. Tang W.H. B-type natriuretic peptide: a critical review. Congest Heart Fail 2007; 13(1): 48-52, http://dx.doi.org/10.1111/ j.1527-5299.2007.05622.x.

7. Levine Y.C., Rosenberg M.A., Mittleman M., Samuel M., Methachittiphan N., Link M., Josephson M.E., Buxton A.E. B-type natriuretic peptide is a major predictor of ventricular tachyarrhythmias. Heart Rhythm 2014; 11(7): 1109-1116, http:// dx.doi.org/10.1016/j.hrthm.2014.04.024.

8. Xin W., Lin Z., Mi S. Does B-type natriuretic peptideguided therapy improve outcomes in patients with chronic heart failure? A systematic review and meta-analysis of randomized controlled trials. Heart Fail Rev 2013; 20(1): 69-80, http://dx.doi. org/10.1007/s10741-014-9437-8.

9. Arakawa K., Himeno H., Kirigaya J., Otomo F., Matsushita K., Nakahashi H., Shimizu S., Nitta M., Takamizawa T., Yano H., Endo M., Kanna M., Kimura K., Umemura S. B-type natriuretic peptide as a predictor of ischemia/ reperfusion injury immediately after myocardial reperfusion in patients with ST segment elevation acute myocardial infarction. Eur Heart J Acute Cardiovasc Care 2015 Jan [Epub ahead of print], http://dx.doi.org/10.1177/2048872615568964.

10. Ejaz N., Khalid M. Utility of brain natriuretic peptide in diagnosis of congestive heart failure and comparison with transthoracic echocardiography: a multicenter analysis in South Asian and Arabian population. J Coll Physicians Surg Pak 2015 Jan; 25(1): 12-15.

11. Lyu T., Zhao Y., Zhang T., Zhou W., Yang F., Ge H., Ding S., Pu J., He B. Natriuretic peptides as an adjunctive treatment for acute myocardial infarction. Int Heart J 2014 Feb; 55(1): 8-16, http://dx.doi.org/10.1536/ihj.13-109.

12. Hu G., Huang X., Zhang K., Jiang H., Hu X. Antiinflammatory effect of $B$-type natriuretic peptide postconditioning during myocardial ischemia-reperfusion: involvement of PI3K/ Akt signaling pathway. Inflammation 2014; 37(5): 1669-1674, http://dx.doi.org/10.1007/s10753-014-9895-0.

13. Shang C. B-type natriuretic peptide-guided therapy for perioperative medicine? Open Heart 2014 Aug; 1(1): e000105, http://dx.doi.org/10.1136/openhrt-2014-000105.

14. Toufektzian L., Zisis C., Balaka C., Roussakis A. Effectiveness of brain natriuretic peptide in predicting postoperative atrial fibrillation in patients undergoing non-cardiac thoracic surgery. Interact Cardiovasc Thorac Surg 2015 Jan [Epub ahead of print], http://dx.doi.org/10.1093/icvts/ivu454.

15. Blinov D.S., Sernov L.N., Balashov V.P., Blinova E.V., Pivkina L.V., Gogina E.D., Van'kova L.V., Vertyankin M.V., Boyko G.G., Krasilina T.V. Anti-ischemic activity of a new domestic antioxidant - 3-hydroxypyridine ethoxydol derivative. Byulleten' Eksperimental'noi Biologii i Meditsiny 2011; 152(11): 514-517.

16. Zamotaeva M.N., Inchina V.I., Chairkin I.N., Drozdov I.A. Experimental substantiation for the use of mexidol and 3-hydroxypyridine fumarate in chronic myocardial injury. Bull Exp Biol Med 2013; 155(2): 212-213, http://dx.doi.org/10.1007/ s10517-013-2115-3.

17. Andreeva N.N. The experimental and clinical aspects of the application of Meksidol in hypoxia. Meditsinskiy al'manakh 2009; 4: 193-197.

18. Bugrova M.L., Kharkovskaya E.E., Yakovleva E.I. The effect of mexidol on atrial natriuretic peptide in langendorf rat heart preparation. Sovremennye tehnologii $v$ medicine 2014; 6(2): 25-31.

19. Bugrova M.L., Yakovleva E.I., Ermolin I.L. The effect of mexidol on synthesis and secretion of atrial natriuretic peptide in cardiac myocytes in early postreperfusion period in experiment. Morfologicheskie vedomosti 2014; 2: 19-25.

20. Mukhina I.V., Rakhcheeva M.V., Bugrova M.L. Natriuretic peptides in cardiovascular system regulation. Nizhegorodskiy meditsinskiy zhurnal 2006; 5: 96-102.

21. Korpachev V.G., Lysenkov S.P., Tell' L.Z. Modeling of clinical death and post-resuscitation disease in rats. Patologicheskaya fiziologiya i eksperimental'naya terapiya 1982; 3: 78-80.

22. Biserova N.M. Metody vizualizatsii biologicheskikh ul'trastruktur. Podgotovka biologicheskikh ob"ektov dlya izucheniya s pomoshch'yu elektronnykh i fluorestsentnykh konfokal'nykh lazernykh mikroskopov [Imaging methods of biological ultrastructures. Preparation of biological objects for the study using electron and fluorescent confocal laser microscopes]. Moscow: Tovarishchestvo nauchnykh izdaniy KMK; 2013; 104 p.

23. Rakhcheeva M.V., Bugrova M.L. Changes in the proportion of A and B-types of granules containing atrial and brain natriuretic peptides in atrial myocytes in vasorenal hypertension in rats. Tsitologiya 2010; 8: 629-633.

24. Weidemann A., Klanke B., Wagner M., Volk T., Willam C., Wiesener M., Eckardt K., Warnecke C. Hypoxia, via stabilization of hypoxia-inducible factor HIF-1 $\alpha$ is a direct and sufficient stimulus for brain-type natriuretic peptide induction. Biochem J 2008; 409(1): 233-242, http://dx.doi.org/10.1042/ bj20070629.

25. Arjamaa O., Nikinmaa M. Hypoxia regulates the natriuretic peptide system. Int J Physiol Pathophysiol Pharmacol 2011; 3(3): 191-201.

26. Ramos L.W.F., Murad N., Goto E., Antônio E.L., Silva J.A.Jr., Tucci P.F., Carvalho A.C. Ischemia/reperfusion is an independent trigger for increasing myocardial content of mRNA B-type natriuretic peptide. Heart Vessels 2009; 24(6): 454-459, http://dx.doi.org/10.1007/s00380-009-1148-z.

27. Bugrova M.L., Yakovleva E.I., Abrosimov D.A. The relationship of synthesis intensity, accumulation and secretion of natriuretic peptide of atrial myocytes with cardiac rhythm regulation in rats in early postperfusion period. Sovremennye tehnologii v medicine 2012; 3: 26-30.

28. Bugrova M.L., Abrosimov D.A., Yakovleva E.I., Baskina O.S., Ermolin I.L. The study on atrial natriuretic peptide of cardiomyocytes in a remote postperfusion period in experiment. Sovremennye tehnologii v medicine 2013; 5(4): 39-44.

29. Watson C., Phelan D., Xu M., Collier P., Neary R., Smolenski A., Ledwidge M., McDonald K., Baugh J. Mechanical 
stretch up-regulates the B-type natriuretic peptide system in human cardiac fibroblasts: a possible defense against transforming growth factor- $\beta$ mediated fibrosis. Fibrogenesis Tissue Repair 2012; 5(1): 9, http://dx.doi.org/10.1186/1755-1536-5-9.
30. Huntley B., Ichiki T., Sangaralingham J., Chen H., Burnett J. B-type natriuretic peptide and extracellular matrix protein interactions in human cardiac fibroblasts. J Cell Physiol 2010 Oct; 225(1), http://dx.doi.org/10.1002/jcp.22253. 